\title{
Zinc ion dyshomeostasis increases resistance of prostate cancer cells to oxidative stress via upregulation of HIF1a
}

\author{
David Wetherell ${ }^{1,2}$, Graham S. Baldwin ${ }^{1}$, Arthur Shulkes ${ }^{1}$, Damien Bolton ${ }^{1,2}$, Joseph \\ Ischia $^{1,2}$ and Oneel Patel ${ }^{1}$ \\ ${ }^{1}$ Department of Surgery, University of Melbourne, Austin Health, Heidelberg, Victoria, 3084, Australia \\ ${ }^{2}$ Department of Urology, Austin Health, Heidelberg, Victoria, 3084, Australia
}

Correspondence to: Oneel Patel, email: patelo@unimelb.edu.au

Keywords: castrate resistant; hypoxia inducible factor 1 alpha; prostate cancer; zinc; iron

Received: September 07, $2017 \quad$ Accepted: November 14, 2017

Published: January 03, 2018

Copyright: Wetherell et al. This is an open-access article distributed under the terms of the Creative Commons Attribution License 3.0 (CC BY 3.0), which permits unrestricted use, distribution, and reproduction in any medium, provided the original author and source are credited.

\section{ABSTRACT}

Zinc ions $\left(\mathrm{Zn}^{2+}\right)$ are known to influence cell survival and proliferation. However the homeostatic regulation of $\mathrm{Zn}^{2+}$ and their role in prostate cancer (PC) progression is poorly understood. Therefore the subcellular distribution and uptake of $\mathrm{Zn}^{2+}$ in PC cells were investigated. Inductively coupled plasma mass spectroscopy and fluorescent microscopy with the $\mathrm{Zn}^{2+}$-specific fluorescent probe FluoZin-3 were used to quantify total and free $\mathrm{Zn}^{2+}$, respectively, in the normal prostate epithelial cell line (PNT1A) and three human PC cell lines (PC3, DU145 and LNCaP). The effects of $\mathrm{Zn}^{2+}$ treatment on proliferation and survival were measured in vitro using MTT assays and in vivo using mouse xenografts. The ability of $\mathrm{Zn}^{2+}$ to protect against oxidative stress via a HIF1a-dependent mechanism was investigated using a HIF1a knock-down PC3 model. Our results demonstrate that the total $\mathrm{Zn}^{2+}$ concentration in normal PNT1A and PC cells is similar, but PC3 cells contain significantly higher free $\mathrm{Zn}^{2+}$ than PNT1A cells $(p<0.01)$. PNT1A cells can survive better in the presence of high concentrations of

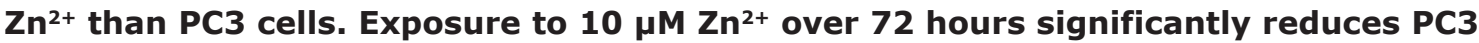
cell proliferation in vitro but not in vivo. $\mathrm{Zn}^{2+}$ increases PC3 cell survival up to 2.3fold under oxidative stress, and this protective effect is not seen in PNT1A cells or in a HIF1a-KD PC3 cell model. A state of $\mathrm{Zn}^{2+}$ dyshomeostasis exists in PC. HIF1a is an integral component of a $\mathrm{Zn}^{2+}$-dependent protective mechanism present in PC3 cells. This pathway may be clinically significant through its contribution to castrateresistant PC survival.

\section{INTRODUCTION}

The essential trace metal zinc, as the divalent $\mathrm{Zn}^{2+}$ ion, is a critical structural component of many proteins including transcription factors, and a component and/or co-factor for $>300$ enzymes [1]. The prostate gland contains a very high concentration of zinc ions particularly in the peripheral zone, where most prostate tumours occur. In a normal prostate epithelial cell, zinc ions inhibit the mitochondrial enzyme aconitase (mAC), and consequently citrate accumulates and is secreted at high concentrations into seminal fluid [2].

Compared to the normal prostate, the $\mathrm{Zn}^{2+}$ concentration in prostate cancer (PC) is reduced by
$80 \%$ [3]. Excessive $\mathrm{Zn}^{2+}$ is toxic to cells, and therefore regulated homeostasis is critical, but the homeostatic mechanism in PC is poorly understood. Human serum $\mathrm{Zn}^{2+}$ concentrations range from 10 to $25 \mu \mathrm{M}$, most of which is bound to proteins, and the interstitial $\mathrm{Zn}^{2+}$ concentration is normally 2 to $5 \mu \mathrm{M}$ [4]. The majority of $\mathrm{Zn}^{2+}$ is tightly bound and considered inactive, and the amount of free $\mathrm{Zn}^{2+}$, which is considered biologically active, is in the $\mathrm{pM}$ to $\mathrm{nM}$ range [5]. Unlike most cells in which $\mathrm{Zn}^{2+}$ is sequestered into vesicles and organelles, in normal prostate cells $35 \%$ of free $\mathrm{Zn}^{2+}$ in located in the cytoplasm and $30 \%$ is sequestered in the mitochondria [6]. The recent development of fluorescent probes specific for the $\mathrm{Zn}^{2+}$ ion 
has made quantifying free $\mathrm{Zn}^{2+}$ achievable via fluorescent microscopy/spectroscopy, but their application in PC has been limited and little is known about the intracellular free $\mathrm{Zn}^{2+}$ concentration, $\mathrm{Zn}^{2+}$ uptake, or the subcellular distribution of $\mathrm{Zn}^{2+}$ in PC cells [7]

$\mathrm{Zn}^{2+}$ treatment has been shown to reverse the effects of oxidative stress in vivo and to increase resistance to chemo- or radiation-induced apoptosis. Therefore, $\mathrm{Zn}^{2+}$ has been implicated in PC survival mechanisms [8]. Hypoxia-inducible factor $1 \alpha$ (HIF $1 \alpha)$ forms part of a transcriptional complex which stimulates the expression of $>200$ survival genes in response to hypoxia. We have previously demonstrated that overexpression of HIF $1 \alpha$ in $\mathrm{PC}$ is an independent indicator for PC recurrence, metastatic spread and progression to castration-resistant prostate cancer (CRPC) [9].

The aims of the present study were to measure baseline free and total $\mathrm{Zn}^{2+}$ concentrations in PC cells and determine the role of $\mathrm{Zn}^{2+}$ in the proliferation of prostate cancer cells in vitro and in vivo. Finally, the ability of $\mathrm{Zn}^{2+}$ to protect against oxidative stress, and in particular the role of $\mathrm{Zn}^{2+}$ in a HIF $1 \alpha$-dependent mechanism, were investigated.

\section{RESULTS}

\section{Intracellular distribution of $\mathrm{Zn}^{2+}$ is altered in CRPC-like cells}

$\mathrm{Zn}^{2+}$ is abundant in prostate tissue, but cellular $\mathrm{Zn}^{2+}$ homeostasis is complex and poorly understood in PC. To address this issue total $\mathrm{Zn}^{2+}$ in normal and PC cell lines was measured by Inductively Coupled Plasma Mass Spectroscopy (ICP-MS), which accurately detects $\mathrm{Zn}^{2+}$ concentrations as low as $0.5 \mathrm{ppb}$. $\mathrm{Zn}^{2+}$ concentrations (ppb) were $52 \pm 8,79 \pm 19,80 \pm 17$ and $57 \pm 5$ for PNT1A, LNCaP, DU145 and PC3 cells, respectively, and there was no significant difference in baseline total $\mathrm{Zn}^{2+}$ concentration between normal and PC cells (Figure 1A).

Nearly all intracellular $\mathrm{Zn}^{2+}$ ions are tightly bound to proteins and are considered inactive with regard to dynamic biological processes. The very small fraction of free $\mathrm{Zn}^{2+}$ ions is biologically active and critical to the physiological functions of the cell. A transformation in the pool of free $\mathrm{Zn}^{2+}$ caused by carcinogenesis could dramatically alter enzymatic reactions and nuclear transcription, thus altering normal cellular functions, including increased survival. Therefore, the concentration $(\mathrm{nM})$ of free $\mathrm{Zn}^{2+}$ ions was quantified using a fluorescent indicator specific for $\mathrm{Zn}^{2+}$ (FluoZin-3) in all four prostate cell lines (Figure 1B). Basal free $\mathrm{Zn}^{2+}$ concentration (nM) was $4.5 \pm 0.2,2.8 \pm 0.3,6.4 \pm 0.3$ and $6.8 \pm 0.5$ in PNT1A, LNCaP, DU145 and PC3 cells, respectively. The CRPClike PC3 and DU145 cells contained significantly higher, and the androgen-sensitive LNCaP cells significantly lower, free $\mathrm{Zn}^{2+}$ compared to PNT1A cells $(p<0.01)$.
To rule out the possibility that a difference in $\mathrm{Zn}^{2+}$ uptake between PC3 and PNT1A cells could account for the higher free $\mathrm{Zn}^{2+}$ in $\mathrm{PC} 3$ cells, intracellular free $\mathrm{Zn}^{2+}$ was measured using FluoZin-3 following treatment of both cell types with $10 \mu \mathrm{M} \mathrm{Zn}{ }^{2+}$. Surprisingly free $\mathrm{Zn}^{2+}$ was actually higher in PNT1A cells than in PC3 cells (Figure $1 C$ ). At a higher $\mathrm{Zn}^{2+}$ concentration of $50 \mu \mathrm{M}$, the fold increase in intracellular free $\mathrm{Zn}^{2+}$ was similar in both cell lines $(p>0.05)$ (Figure 1D). Thus the increased free $\mathrm{Zn}^{2+}$ in PC3 cells is not due to more rapid $\mathrm{Zn}^{2+}$ uptake.

To investigate further the disparity in $\mathrm{Zn}^{2+}$ homeostasis between PC3 and PNT1A cells, the distribution of $\mathrm{Zn}^{2+}$ was evaluated using MitoTracker Red FM (a far red-fluorescent mitochondrial dye) and Hoechst 33342 (a blue nuclear DNA stain) in combination with FluoZin-3 (a green $\mathrm{Zn}^{2+}$ indicator). Untreated PC3 cells (Figure 2A) appeared to have larger, distinct intracellular $\mathrm{Zn}^{2+}$ pools, which were located more peripherally than in PNT1A cells (Figure 2B). Following exposure to $10 \mu \mathrm{M} \mathrm{ZnCl}, \mathrm{Zn}^{2+}$ was rapidly $(30 \mathrm{~min}$ ) co-localised to the mitochondria in both cell lines as assessed by coalescence of green and red fluorescence to form yellow. This phenomenon persisted for up to $120 \mathrm{~min}$ in PNT1A cells, and beyond $240 \mathrm{~min}$ in PC3 cells, before distinct $\mathrm{Zn}^{2+}$ pools reappeared similar to the appearance of untreated control cells. The scatter plots in Figure 2A and Figure 2B illustrate the prolonged co-localisation of $\mathrm{Zn}^{2+}$ to the mitochondria. The Pearson correlation coefficient (PCC) has been recommended as the gold-standard assessment tool to quantify the degree of co-localisation between two fluorophores [10]. $\mathrm{Zn}^{2+}$ was localised to the mitochondria in both the cell lines at $120 \mathrm{~min}$ post $\mathrm{Zn}^{2+}$ treatment, however at $240 \mathrm{~min}$ a clear divergence in behaviour of each cell line was visible with PNT1A cells rapidly returning to the pre-treatment distribution but PC3 cells continuing to localise $\mathrm{Zn}^{2+}$ to the mitochondria $(p<$ 0.001) (Figure 2C). Thus baseline free $\mathrm{Zn}^{2+}, \mathrm{Zn}^{2+}$ uptake and subsequent subcellular distribution of $\mathrm{Zn}^{2+}$ in CRPClike PC cells was strikingly different to normal prostate epithelial cells.

\section{Exogenous $\mathrm{Zn}^{2+}$ is cytotoxic to prostate cells at high doses}

The effect of zinc ions on prostate cell lines was investigated in vitro in order to ascertain the sensitivity to $\mathrm{Zn}^{2+}$ of normal prostate cells compared to cancer cells. The dose-response of normal prostate (PNT1A), androgensensitive (LNCaP) and CRPC-like prostate cancer cells (PC3) to $\mathrm{Zn}^{2+}\left(\mathrm{ZnCl}_{2}\right)$ was measured using an MTT cell survival/proliferation assay. All cell lines tolerated exposure to low $\mathrm{ZnCl}_{2}$ concentrations $(12.5 \mu \mathrm{M})$ for 24 hours with 93\%, 91\% and $113 \%$, of PC3, LNCaP and PNT1A cells surviving, respectively (Figure 3A). However, at $25 \mu \mathrm{M}$ $\mathrm{Zn}^{2+}$ cell survival was $19 \%$ in PC3 and $28 \%$ in $\mathrm{LNCaP}$ compared to $104 \%$ in PNT1A cells. Furthermore at a 
higher concentration $(50 \mu \mathrm{M}) \mathrm{Zn}^{2+}$ was cytotoxic to all three cell lines. This observation suggests that normal prostate epithelial cells can survive better in the presence of higher concentrations of $\mathrm{Zn}^{2+}$ than prostate cancer cells.

Accumulation and utilisation of $\mathrm{Zn}^{2+}$ is a significant property of prostate epithelial cells. We investigated the effect of $\mathrm{Zn}^{2+}$ on $\mathrm{PC}$ cell proliferation in vitro and in vivo. A low well tolerated dose of $\mathrm{ZnCl}_{2}(10 \mu \mathrm{M})$ was selected for a long-term (72 hour) MTT cell proliferation assay. At 72 hours relative cell numbers increased 3.8 \pm 0.5 fold in $\mathrm{Zn}^{2+}$-treated PC3 cells, and the increase was significantly lower than in untreated cells which increased by $6.6 \pm 0.8$ fold $(p<0.001)$ (Figure 3B). Exposure to $\mathrm{Zn}^{2+}$ had a significant effect on proliferation of PNT1A but no effect on LNCaP cells (Figure 3C and 3D). The possibility that serum starvation might affect the viability was confirmed in the case of normal prostate PNT1A cells as viability was decreased at the $72 \mathrm{hr}$ time point under serum starvation either in the presence or
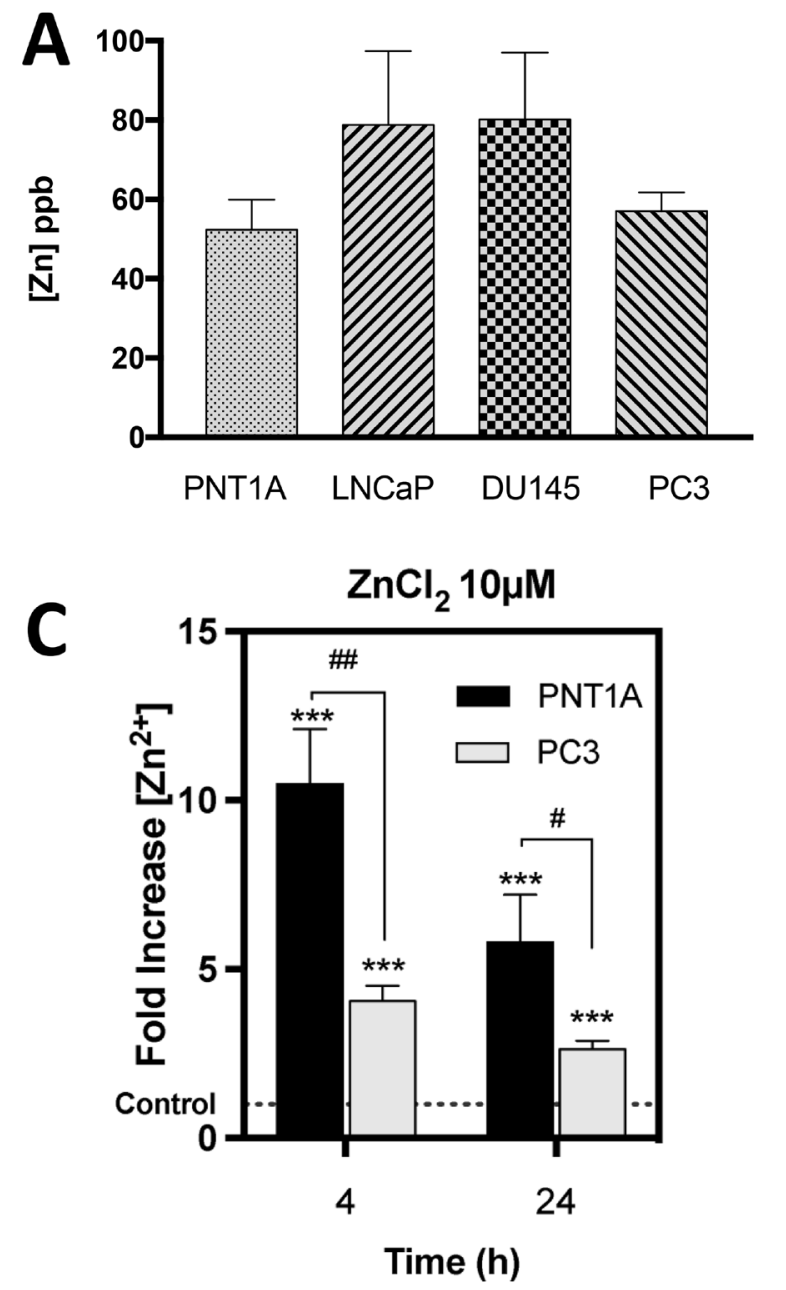

absence of zinc (Ctrl). In contrast cancer ous LNCaP and PC3 cells maintained viability over $72 \mathrm{hr}$.

To supplement the in vitro observations of the effects of $\mathrm{Zn}^{2+}$ on PC cell proliferation, SCID mice with established PC3 xenograft tumours were injected twice weekly with $\mathrm{ZnCl}_{2}$ (3 $\mathrm{mg} / \mathrm{kg}$ or $10 \mathrm{mg} / \mathrm{kg}$ ) (Figure $3 \mathrm{E}$ ). Mice were randomised (up to $n=7$ per group) to either $\mathrm{Zn}^{2+}$-treated or control groups. Tumour volumes $\left(\mathrm{mm}^{3}\right)$ were measured daily with micro-callipers and the values expressed as percentage increase compared to day zero. No significant difference in tumour volume was observed over the 2 week treatment period. In addition, treatment with the $\mathrm{Zn}^{2+}$ chelator TPEN at $3 \mathrm{mg} / \mathrm{Kg}$ or $10 \mathrm{mg} / \mathrm{Kg}$ had no effect on tumour growth. Thus $\mathrm{Zn}^{2+}$ does not stimulate or inhibit prostate tumour growth in vivo. Furthermore a higher dose of $\mathrm{Zn}^{2+}(20 \mathrm{mg} / \mathrm{Kg})$ was toxic and all mice in this treatment group were culled after a maximum of 2 doses (data not presented). A higher dose of TPEN (20 mg/ $\mathrm{Kg})$ also resulted in toxicity.
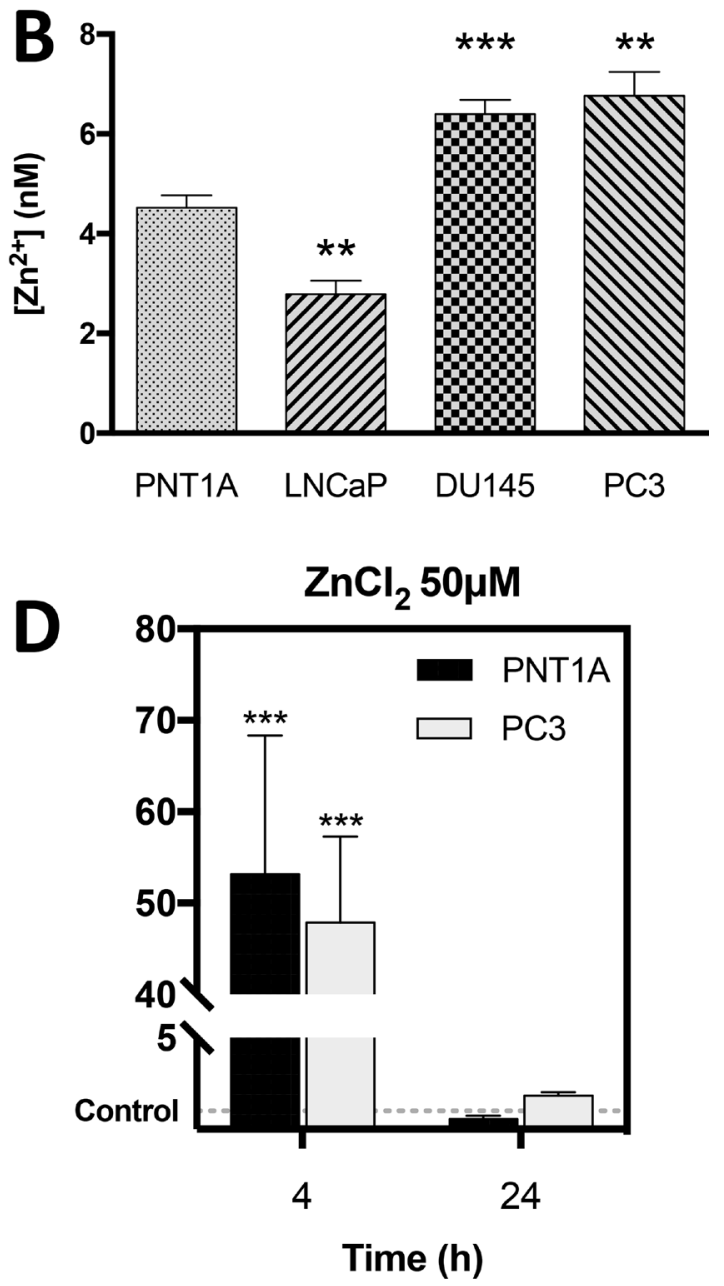

Figure 1: CRPC-like cells contain significantly higher basal free $\mathbf{Z n}^{2+}$ ions but equal total zinc compared to normal controls. (A) Total zinc concentration (ppb) measured by Inductively Coupled Plasma Mass Spectroscopy (ICP-MS) in untreated PNT1A, LNCaP, DU145 and PC3 cells. (B) Baseline intracellular free zinc $\left(\mathrm{Zn}^{2+}\right)$ concentration (nM) was measured using a FluoZin-3 fluorescent probe in the same 4 prostate cell lines. $\mathrm{Zn}(\mathrm{nM})=\mathrm{Kd} x(\mathrm{~F}-\mathrm{Fmin}) /(\mathrm{Fmax}-\mathrm{F})$ was used to calculate zinc concentration. Intracellular $\mathrm{Zn}^{2+}$ uptake following exposure to $10 \mu \mathrm{M}(\mathbf{C})$ or $50 \mu \mathrm{M}$ (D) $\mathrm{ZnCl}_{2}$ for 4 or 24 hours was measured in PNT1A and PC3 cells. ${ }^{* * *} p<0.001$ PNT1A vs. PC3 ${ }^{\# \#} p<0.05$ and ${ }^{\# \#} p<0.01$. Values are expressed as the mean \pm SEM of at least three separate experiments. 

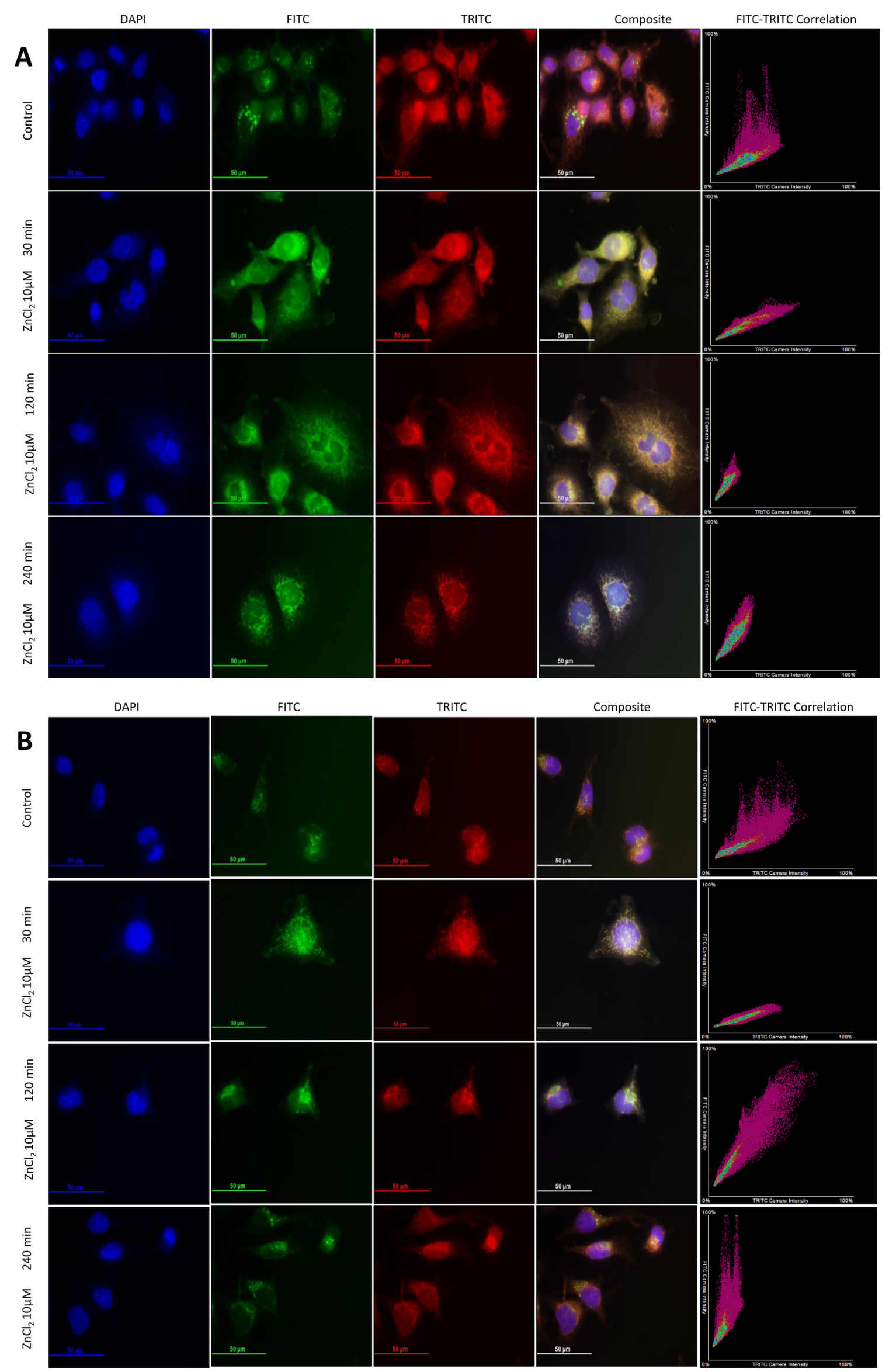


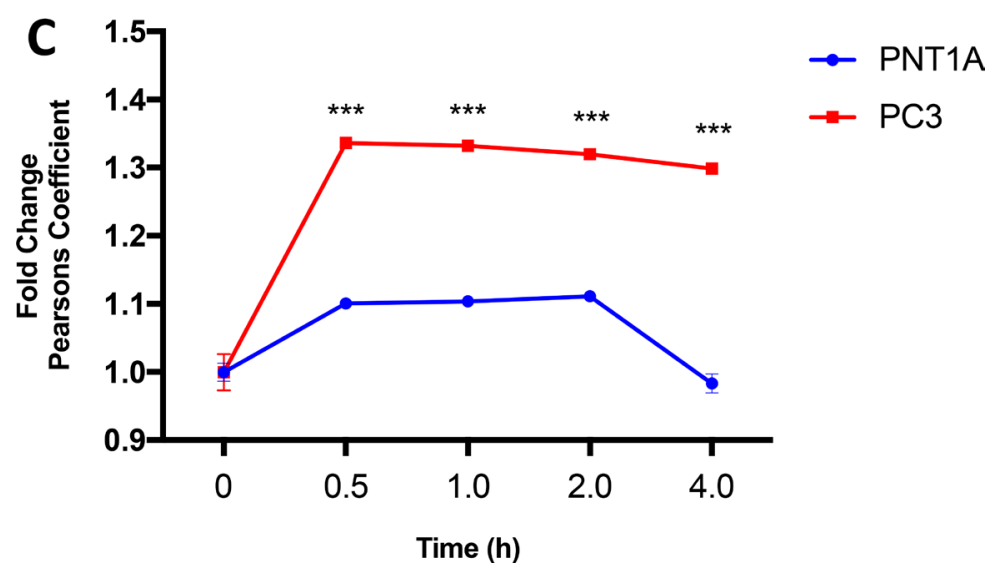

Figure 2: Co-localisation of $\mathbf{Z n}^{2+}$ to mitochondria in prostate cells. (A) PC3 cells and (B) PNT1A cells were exposed to 10 $\mu \mathrm{M} \mathrm{ZnCl}$ for 30, 120 and 240 minutes and stained with Hoechst (DAPI), FluoZin-3 (FITC) and MitoTracker (TRITC) fluorescent dyes. Immunofluorescent microscopy images were acquired at 60× (oil immersion) magnification using a Nikon DS-Qi 1Mc Camera with 250 $\mathrm{ms}, 120 \mathrm{~ms}$ and $35 \mathrm{~ms}$ exposure times for DAPI, FITC and TRITC channels respectively. Composite images were created by merging blue (DAPI), green (FITC) and red (TRITC) channels. FITC and TRITC colour intensity for each pixel in the corresponding composite image is plotted on scatter plots. (C) Co-localisation of $\mathrm{Zn}^{2+}$ to mitochondria for PNT1A and PC3 cells was estimated using Pearson correlation coefficient between FITC (FluoZin-3) and TRITC (MitoTracker) colours. Values are expressed as fold change compared to time 0 hours. Statistical significance for the PNT1A vs. PC3 comparison was determined using the Bonferroni-Sidak method with $\alpha=0.05 .{ }^{* * *} p<0.001$. Values are expressed as the mean $\pm \mathrm{SEM}$ of at least three separate experiments.
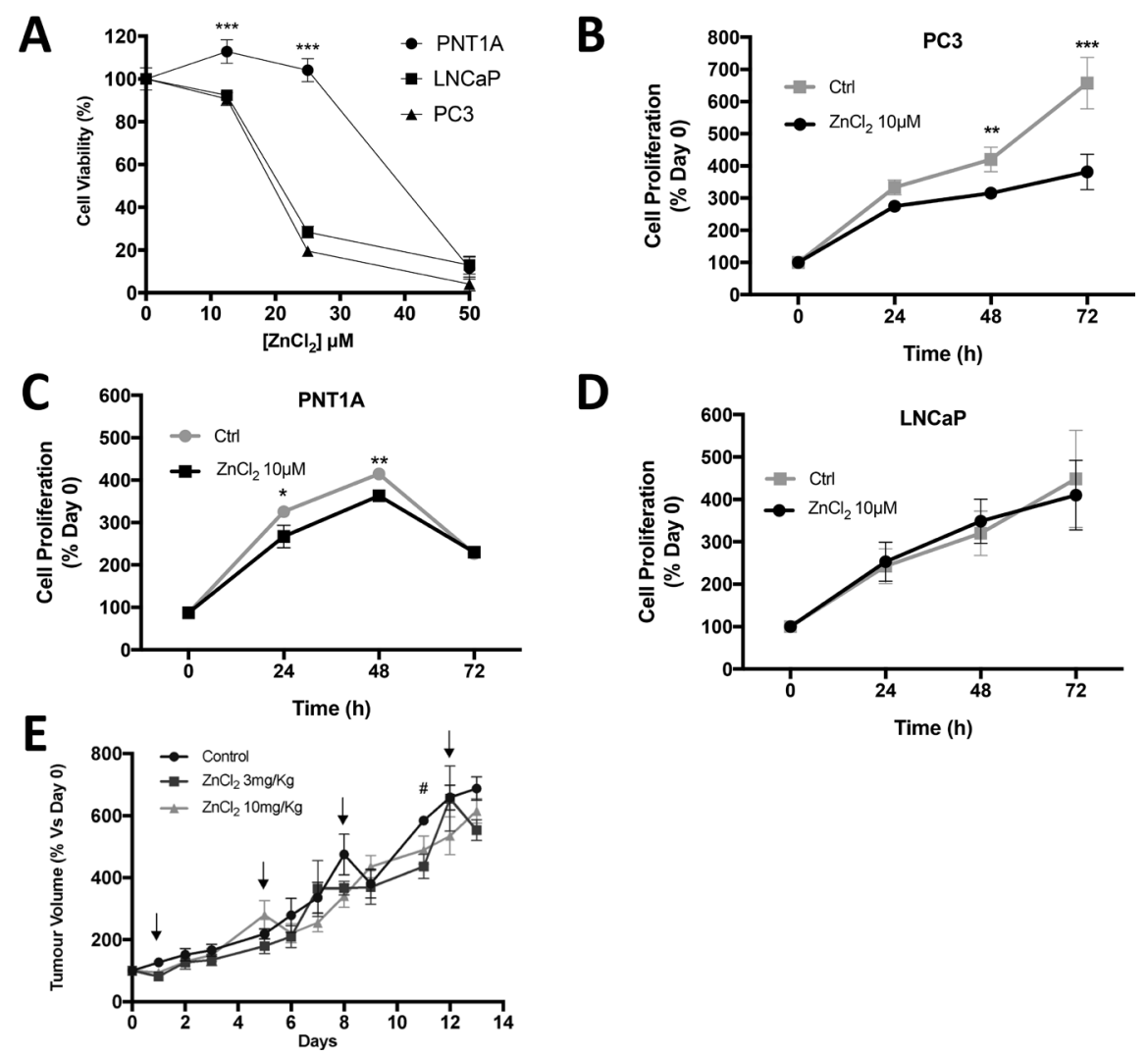

Figure 3: Zinc chloride treatment inhibits in vitro cell proliferation in CRPC-like PC3 cells. (A) Cell viability in PNT1A, $\mathrm{LNCaP}$ and PC3 cells after 48 hours of exposure to various concentration of $\mathrm{ZnCl}_{2}$ was analysed by MTT assay. Proliferation of cells exposed to serum-free medium only $(\mathrm{Ctrl})$ or to $\mathrm{ZnCl}_{2}$ was assessed by MTT assay at $0,24,48$ and 72 hours respectively in $(\mathbf{B})$ PC3, (C) PNT1A and (D) LNCaP cells. Statistical analysis using one-way ANOVA (Ctrl vs. Zinc) was performed ${ }^{*} p<0.05,{ }^{* *} p<0.01$ and ${ }^{* * *} p<$ 0.001. Values are expressed as the mean \pm SEM of at least three separate experiments. (E) PC3 xenograft tumour volume in SCID mice in three treatment arms: control $(n=7), \mathrm{ZnCl}_{2} 3 \mathrm{mg} / \mathrm{Kg}(n=3)$ and $\mathrm{ZnCl}_{2} 10 \mathrm{mg} / \mathrm{Kg}(n=7)$. Arrows represent the days of $\mathrm{ZnCl}_{2}$ or saline (control) IP injection. The percentage increase compared to day 0 was calculated and the mean \pm SEM plotted. Statistical analysis was calculated by two-way ANOVA. ${ }^{*} p<0.05, \mathrm{ZnCl}_{2} 3 \mathrm{mg} / \mathrm{Kg}$ versus control. 


\section{$\mathrm{Zn}^{2+}$ augments resistance of $\mathrm{PC} 3$ cells to oxidative stress}

Our previously published study revealed that LNCaP cells, which contain low free $\mathrm{Zn}^{2+}$, are more sensitive to oxidative stress than $\mathrm{PC} 3$ cells, which contain high free $\mathrm{Zn}^{2+}$ [9]. Therefore, we hypothesized that the higher free $\mathrm{Zn}^{2+}$ concentration in CPRC-like DU145 and PC3 cells, compared to either normal prostate PNT1A cells or androgen sensitive LNCaP cells, may be responsible for the increased resistance of CRPC-like cells to various stresses. Indeed the basal IC50 value for resistance to $\mathrm{H}_{2} \mathrm{O}_{2}$ was significantly higher at 45.3 $\mu \mathrm{M}$ for PC3 cells compared to $1.8 \mu \mathrm{M}$ in PNT1A cells (Figure 4A). Furthermore exogenous $\mathrm{Zn}^{2+}$ can further increase resistance to oxidative stress by $\mathrm{H}_{2} \mathrm{O}_{2}$ in $\mathrm{PC} 3$ cells (with a maximal 2.3 fold greater survival at $10 \mu \mathrm{M} \mathrm{Zn}^{2+}$ ) (Figure 4B), but not in benign PNT1A cells (Figure 4C).

\section{$\mathrm{Zn}^{2+}$ induces HIF1 $\alpha$ in prostate cancer cells}

HIF $1 \alpha$ is a transcription factor that initiates molecular responses to protect against cellular injury.
Expression of HIF $1 \alpha$ is upregulated by hypoxia and also by $\mathrm{Zn}^{2+}$ ions [11]. We have previously demonstrated that HIF $1 \alpha$ is overexpressed in PC3 compared to LNCaP cells under normoxic conditions and that it contributes to resistance to $\mathrm{H}_{2} \mathrm{O}_{2}$ and chemotherapeutics such as 5 -fluorouracil [9]. Therefore in this study, the basal expression of HIF $1 \alpha$ in PNT1A cells, which contain low concentrations of free $\mathrm{Zn}^{2+}$, was compared to PC3 cells. Basal expression of HIF $1 \alpha$ was significantly greater $(21 \pm$ 5 fold) in PC 3 cells compared to LNCaP cells $(p<0.01)$ (Figure 5A). Interestingly, normal PNT1A cells expressed up to $4.5 \pm 2.3$ fold more $\mathrm{HIF} 1 \alpha$ protein than $\mathrm{LNCaP}$ cells, and another CRPC-like cell line (DU145) expressed $12.0 \pm 3.6$ fold higher HIF $1 \alpha$ protein. Overall there was a linear correlation $\left(\mathrm{r}^{2}=0.97\right)$ between HIF $1 \alpha$ expression and concentration of free $\mathrm{Zn}^{2+}$ in untreated normal prostate epithelial and PC cell lines (Figure 5B). Exogenous $\mathrm{Zn}^{2+}$ further increased expression of HIF $1 \alpha$ in a dose- and timedependent manner in $\mathrm{PC} 3$ cells, with a maximal increase of $8.9 \pm 2.4$ fold at $10 \mu \mathrm{M} \mathrm{Zn}^{2+}$ (Figure 5C). Maximal stimulation of HIF $1 \alpha$ expression was observed in PNT1A cells at $50 \mu \mathrm{M} \mathrm{Zn}^{2+}$, a concentration which was cytotoxic to PC3 cells (Figure 5D). HIF1 $\alpha$ stimulation by $\mathrm{Zn}^{2+}$ in
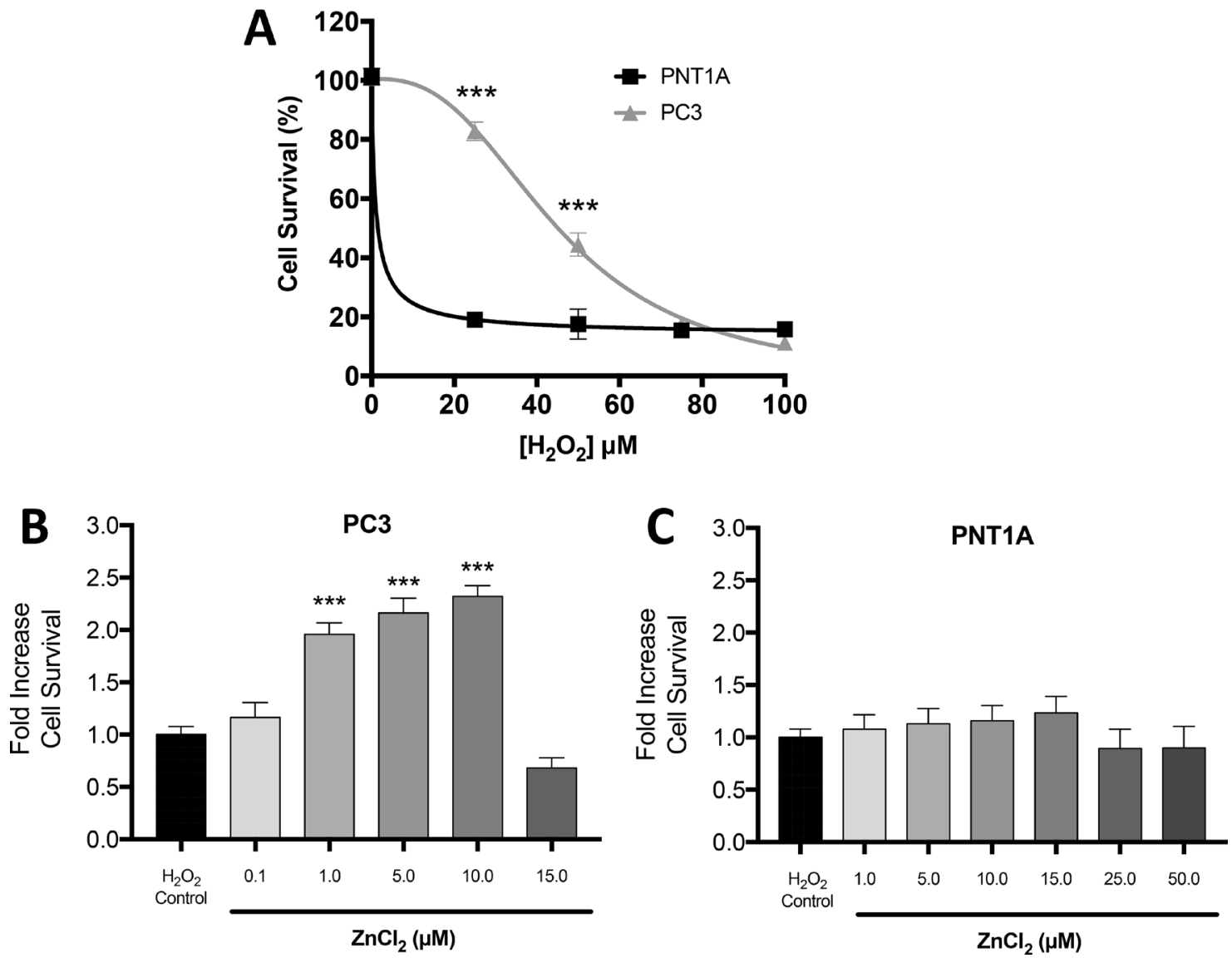

Figure 4: $\mathrm{Zn}^{2+}$ mediated protection against oxidative stress injury in PC3 cells. (A) Cell survival/proliferation was measured by MTT assay. The data demonstrates increased resilience in PC3 cells compared to PNT1A under oxidative stress induced by increasing concentrations of $\mathrm{H}_{2} \mathrm{O}_{2}$. Cell survival was measured by MTT assay in (B) PC3 and (C) PNT1A cells preconditioned with the indicated concentrations of $\mathrm{ZnCl}_{2}$ for 4 hours followed by oxidative stress $\left(75 \mu \mathrm{M} \mathrm{H}_{2} \mathrm{O}_{2}\right.$ for 24 hours). Values are expressed as the mean $\pm \mathrm{SEM}$ of at least three separate experiments. 
PC3 cells was time dependent and occurred as rapidly as 2 $\mathrm{h}$ post-exposure (Figure 5E). Increased HIF $1 \alpha$ expression was only seen after $24 \mathrm{~h}$ in PNT1A cells (Figure 5F).

\section{Resistance to oxidative stress in PC3 cells is regulated by HIF1a}

Having observed a protective effect of exogenous $\mathrm{Zn}^{2+}$ in wild-type PC3 cells, in order to test the hypothesis that this protection was HIF $1 \alpha$ dependent, the ability of $\mathrm{Zn}^{2+}$ to protect against oxidative stress was examined in a clone of PC3 cells which had been transfected with HIF $1 \alpha$ shRNA (HIF $1 \alpha$ knock-down or HIF $1 \alpha-$ KD cells) [9]. As demonstrated in Figure 6A, HIF $1 \alpha$ expression in the HIF $1 \alpha-\mathrm{KD}$ cell line was reduced by nearly $50 \%$ to $0.50 \pm 0.06$ fold compared to wild-type PC3 cells. Preconditioning with $\mathrm{ZnCl}_{2}(10 \mu \mathrm{M}$ for 4 hours $)$ significantly increased HIF $1 \alpha$ expression by $15.4 \pm 3.5$ fold in PC3 cells $(p<0.001)$ (Figure 6B). A smaller fold increase in HIF $1 \alpha$ expression of $4.5 \pm 1.5$ was observed in HIF $1 \alpha-\mathrm{KD}$ PC3 cells. Furthermore, in the HIF $1 \alpha-K D$ PC 3 cell line a significant protective effect of $\mathrm{Zn}^{2+}$ pre-conditioning against oxidative injury was not observed (Figure 6C), unlike the previous results in wild-type PC3 cells (Figure 4B). The reduction in the protection conferred by $\mathrm{Zn}^{2+}$ in HIF $1 \alpha-\mathrm{KD}$ cells implies that HIF $1 \alpha$ is an important component of the $\mathrm{Zn}^{2+}$-dependent protective mechanism present in PC3 cells. However, as there was some protection still evident in the $\mathrm{Zn}^{2+}$-pre-conditioned HIF1 $\alpha$-KD cells, $\mathrm{Zn}^{2+}$ ions might be activating alternate mechanisms.

\section{$\mathrm{Zn}^{2+}$ ions competitively inhibit HIF1a degradation by displacing $\mathrm{Fe}^{2+}$ ions}

In many cell types HIF1 $\alpha$ is degraded under normoxic conditions by two key sequential processes: firstly the hydroxylation of HIF- $\alpha$ subunits, by prolylhydroxylase (PHD) enzymes in an oxygen- and iron $\left(\mathrm{Fe}^{2+}\right)$-dependent reaction, promotes binding to the $\mathrm{pVHL}$ E3-ubiquitin complex, and secondly HIF1 $\alpha$ is destroyed by proteasomal degradation [12]. However, in PC cells under normoxia HIF1 $\alpha$ degradation is minimal and there is no decrease in HIF $1 \alpha$ translational activity. The exact mechanism is unknown but the available evidence suggests that $\mathrm{Zn}^{2+}$ ions compete with $\mathrm{Fe}^{2+}$ ions for binding at the active sites of PHDs [13, 14]. In agreement with this hypothesis treatment of CRPC-like cells, which in normoxic conditions over-express HIF1 $\alpha$, with ammonium
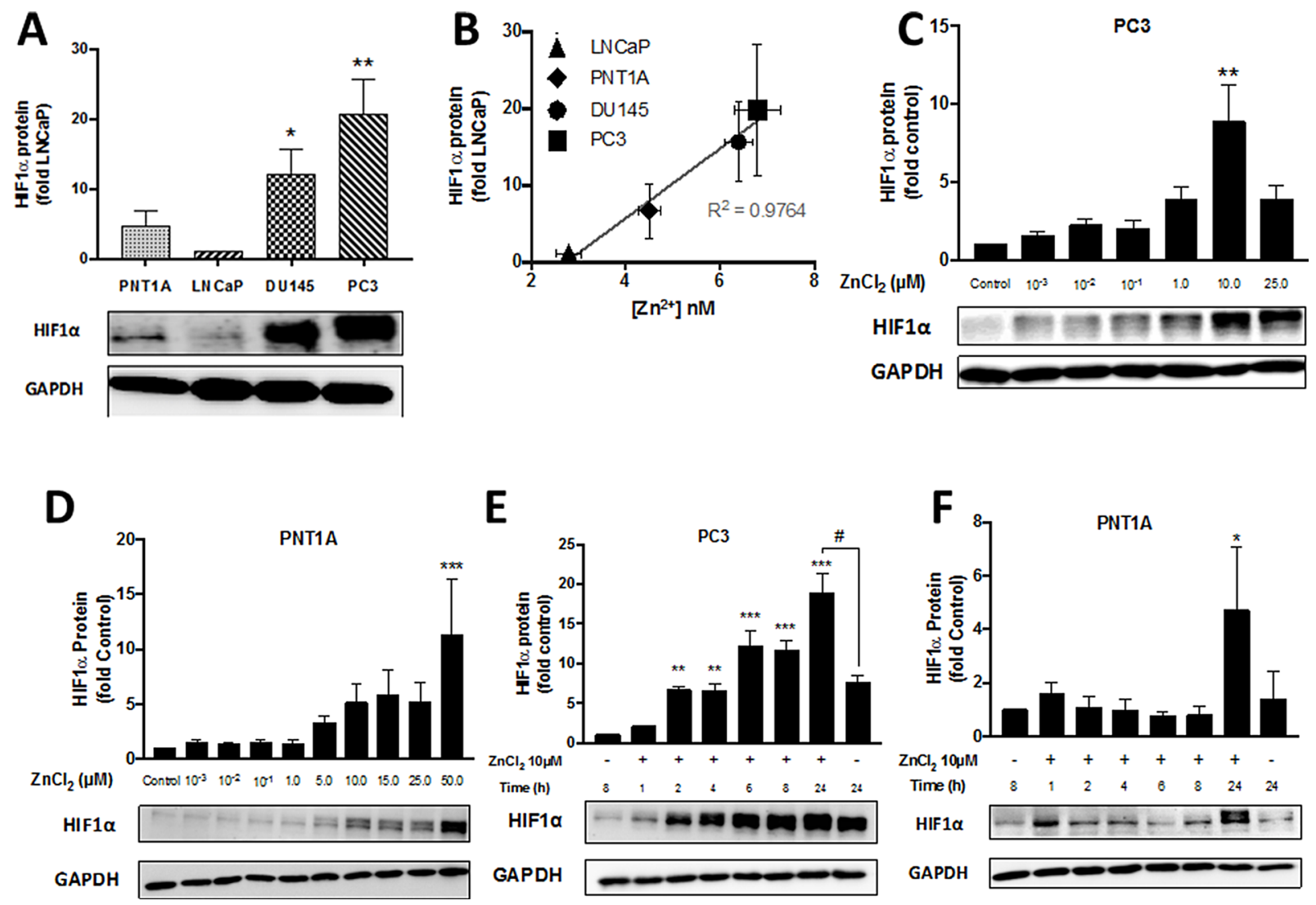

Figure 5: $\mathrm{Zn}^{2+}$ induces HIF1a protein expression in PC3 cells in a time- and dose-dependent manner. (A) Baseline normoxic HIF1 $\alpha$ expression is high and (B) correlates with free $\mathrm{Zn}^{2+}$ concentration in PC cells. HIF1 $\alpha$ protein expression following treatment with increasing concentrations of $\mathrm{ZnCl}_{2}$ for 24 hours was analysed by Western blot in (C) PC3 and (D) PNT1A cells. Zinc ionstimulated HIF $1 \alpha$ protein expression was measured at the indicated times by Western blot in (E) PC 3 and $(\mathbf{F})$ PNT1A cells. ${ }^{*} p<0.05,{ }^{* *} p<$ 0.01 and ${ }^{* * *} p<0.001$. Values are expressed as the mean \pm SEM of at least three separate experiments. 
ferric citrate (AFC) resulted in the degradation of HIF $1 \alpha$ to $29 \%$ and $20 \%$ in DU145 and PC3 cells, respectively, compared to untreated control cells (Figure 7A). More importantly, in the presence of iron, $\mathrm{Zn}^{2+}$ rescued HIF $1 \alpha$ expression by $3.5 \pm 0.95$ fold compared to virtually complete degradation of the HIF $1 \alpha$ protein in cells treated with AFC alone $(p<0.05)$ (Figure 7B). These observations are consistent with the above hypothesis that $\mathrm{Zn}^{2+}$ ions stabilise the HIF1 $\alpha$ protein in the presence of oxygen in PC cells by competing with $\mathrm{Fe}^{2+}$ ions for binding at the PHD active site (Figure 7D).

\section{DISCUSSION}

$\mathrm{Zn}^{2+}$ is essential for cell proliferation and especially for the regulation of DNA synthesis and mitosis, and $\mathrm{Zn}^{2+}$

A
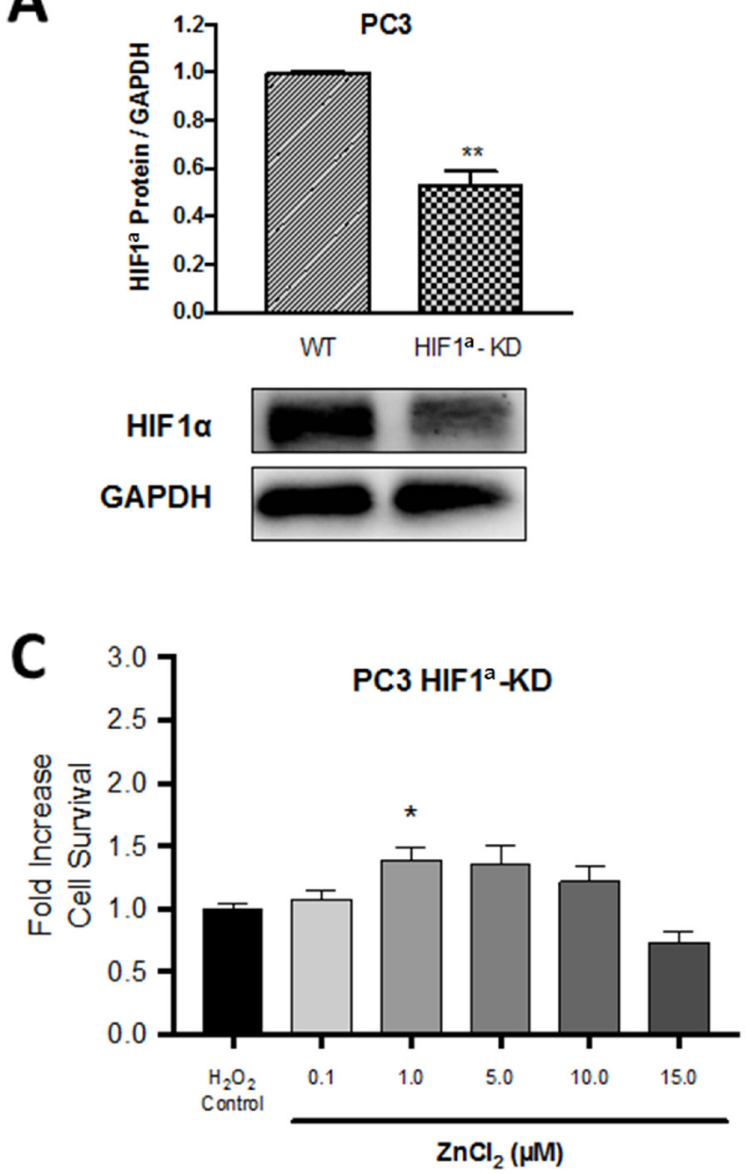

deficiency leads to inhibition of growth $[15,16] . \mathrm{Zn}^{2+}$ stimulates Hep-2 tumour cell proliferation and mitogenic signalling [17], and conversely inhibits proliferation and invasion/migration in some cells including prostate cancer cells [18]. In this study, we have demonstrated that exogenous $\mathrm{Zn}^{2+}$ (greater than $15 \mu \mathrm{M}$ ) is cytotoxic to prostate cancer cells in vitro. Furthermore as normal PNT1A prostate cells had higher $\mathrm{IC}_{50}$ values for $\mathrm{Zn}^{2+}$ toxicity compared to prostate cancer PC3 cells we concluded that prostate cancer cells are more sensitive to the cytotoxic effect of $\mathrm{Zn}^{2+}$ compared to normal cells. In another study, $\mathrm{IC}_{50}$ values of $\mathrm{Zn}^{2+}$ treatments were $194 \mu \mathrm{M}$ for non-tumour PNT1A cells and $94 \mu \mathrm{M}$ for PC3 tumour cells [19]. The discrepancy in $\mathrm{IC}_{50}$ values between the two studies may be attributed to the fact that MTT assays in the Masarik et al. study were carried out in the presence of FBS which would

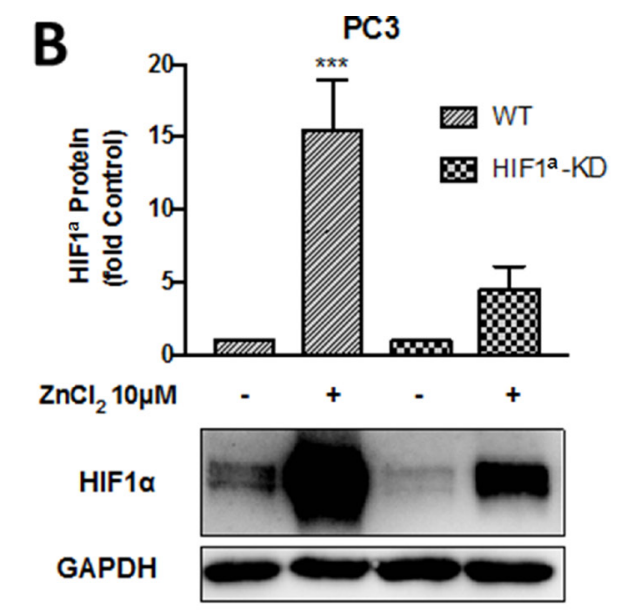

Figure 6: The protective role of $\mathrm{Zn}^{2+}$ against oxidative injury in PC3 cells is HIF1 $\alpha$ dependent. A HIF1 $\alpha$ knock-down PC3 cell line (HIF1 $\alpha-\mathrm{KD}$ ) was created by transfection of a shRNA vector expressing HIF1 $\alpha$ into wild-type (WT) PC3 cells resulting in (A) suppression of HIF1 $\alpha$ expression on Western blot. (B) HIF1 $\alpha$ protein expression in PC3-WT and PC3-HIF1 $\alpha$-KD cells following pre-treatment with $10 \mu \mathrm{M} \mathrm{ZnCl}_{2}$ for 4 hours was measured by Western blot. (C) Survival/proliferation was measured by MTT assay in $\mathrm{HIF} 1 \alpha-\mathrm{KD}$ cells following preconditioning with $\mathrm{ZnCl}_{2}$ for 4 hours then exposure to oxidative stress $\left(75 \mu \mathrm{M} \mathrm{H}_{2} \mathrm{O}_{2}\right.$ for 24 hours). Values are expressed as the mean $\pm \mathrm{SEM}$ of at least three separate experiments. 
confer a putative survival advantage [20,21]. Our results are in agreement with a previous study where CRPC-like DU145 cells were shown to be more sensitive to $\mathrm{Zn}^{2+}$ than another normal prostate cancer cell line RWPE-1 [22]. Overall, these observations suggest $\mathrm{Zn}^{2+}$ has a cytotoxic effect on prostate cancer cells in vitro and, because of this anti-proliferative effect, $\mathrm{Zn}^{2+}$ has been hypothesised to be a tumour suppressor in prostate cancer [23].

However, if $\mathrm{Zn}^{2+}$ is to be effective as an anti-cancer therapy, its cytotoxic effects need to be observed in vivo. Shah et al. [24] injected zinc acetate directly into PC3 xenograft tumours and observed a significant reduction in tumour volume. The concentration of $\mathrm{Zn}^{2+}$ administered in the Shah et al. study [24] equates to $3 \mathrm{mM} \mathrm{ZnCl}_{2}$, which would immediately be toxic to both normal and cancerous cells, as demonstrated in vitro in (Figure 3A). Although intra-tumoural injection in a mouse xenograft tumour model is achievable, the multifocal nature of prostate tumours limits its application in the clinic. Previously a mouse xenograft study using PC3 cells demonstrated that a sustained subcutaneous dosage of zinc sulfate $(0.51 \mathrm{mg}$ elemental $\mathrm{Zn}$ over 28 days) increased the plasma $\mathrm{Zn}^{2+}$ concentration by $\sim 90 \%$, and resulted in $\sim 50 \%$ inhibition $(P$ $<0.05)$ of tumour growth $[25,26]$. In contrast, our results demonstrated that $10 \mathrm{mg} / \mathrm{kg} \mathrm{ZnCl}_{2}(0.4 \mathrm{mg}$ elemental $\mathrm{Zn}$ over 14 days) treatment has neither an accelerating nor inhibiting effect on tumour growth (Figure 3E). Previously a single intra-peritoneal injection of $10 \mathrm{mg} / \mathrm{kg}$ $\mathrm{ZnCl}_{2}$ into SCID mice has been shown to increase free intracellular $\mathrm{Zn}^{2+}$ and induce gastrin gene expression in colon cancer cells grown as xenograft tumours [21] and two subcutaneous injections of $10 \mathrm{mg} / \mathrm{kg} \mathrm{ZnCl}$ into rats protects against renal ischemia reperfusion injury [11]. This suggests that $\mathrm{ZnCl}_{2}$ at a10 $\mathrm{mg} / \mathrm{kg}$ dose is able to stimulate a multitude of biological effects without any toxicity. It could be argued that the $10 \mathrm{mg} / \mathrm{kg} \mathrm{ZnCl}_{2}$ dose was not enough to cause anti-tumour effects and that a higher $\mathrm{Zn}^{2+}$ dose would have reduced tumour growth. However the fact that $20 \mathrm{mg} / \mathrm{kg} \mathrm{ZnCl}$ resulted in severe toxicity in mice precludes the use of high doses of $\mathrm{Zn}^{2+}$.
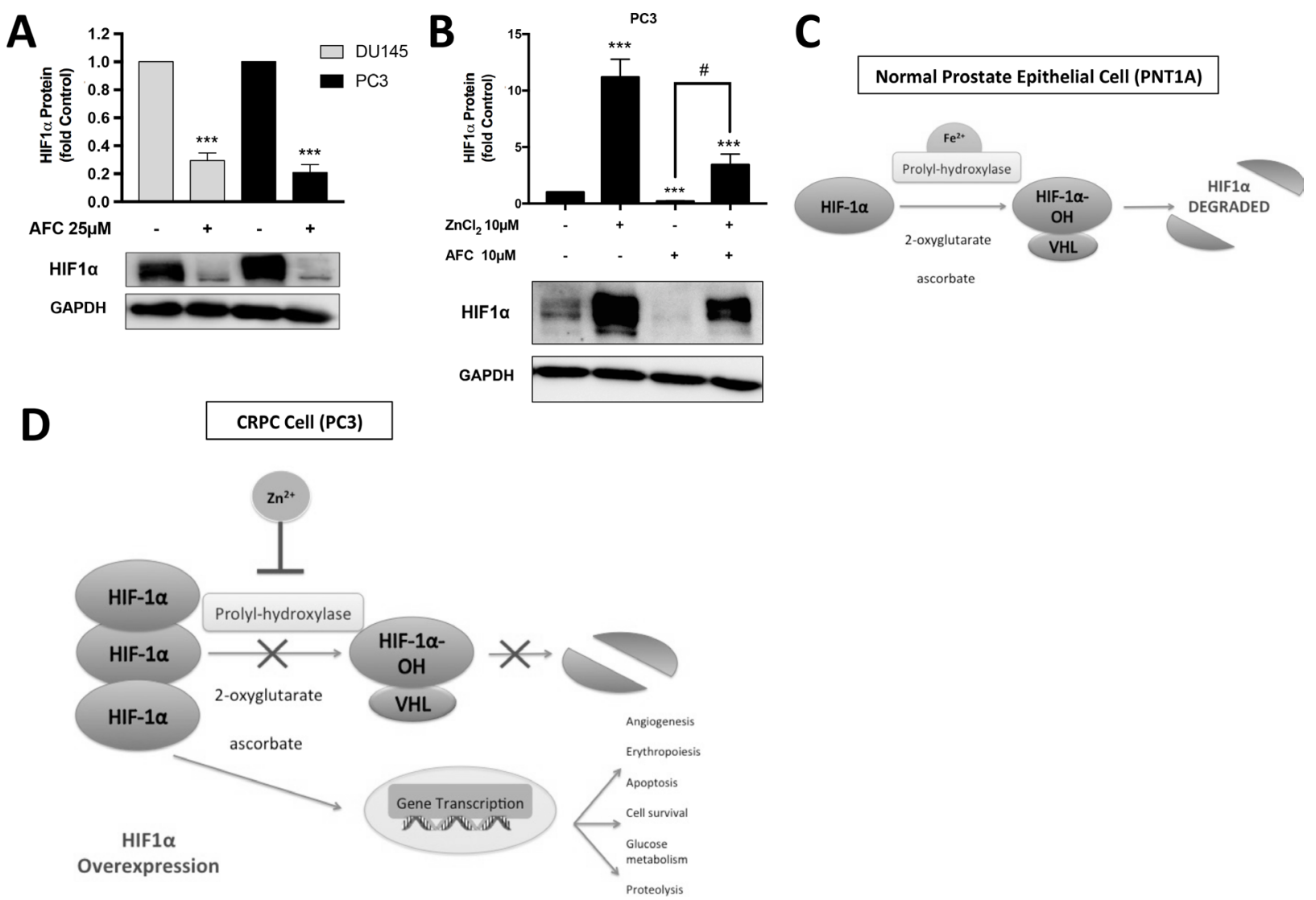

Figure 7: $\mathbf{Z n}^{2+}$ ions competitively inhibit HIF1 $\alpha$ degradation by displacing Fe F $^{2+}$ ions. (A) HIF $1 \alpha$ protein was degraded in the presence of ammonium ferric citrate (AFC) in DU145 and PC3 cells. (B) The reduction in HIF1 $\alpha$ expression in the presence of iron was partially reversed by $\mathrm{Zn}^{2+}$ in PC3 cells. Values are expressed as the mean \pm SEM of at least three separate experiments. (C) In a normal prostate epithelial cell (PNT1A) under normoxic conditions, the pathway for HIF1 $\alpha$ degradation pathway is activated. Proteasomal degradation is achieved by binding to the pVHL-E3-ubiquitin complex mediated by prolyl-hydroxylase (PHD) enzymes which require the co-factors iron $\left(\mathrm{Fe}^{2+}\right)$, ascorbate and 2-oxoglutarate. (D) In CRPC cells (PC3) under the same normoxic conditions the HIF1 $\alpha$ pathway is inhibited by $\mathrm{Zn}^{2+}$ ions, which substitute for $\mathrm{Fe}^{2+}$ ions at the PHD binding site, and also potentially reduce the co-factor 2-oxoglutarate via $\mathrm{mAC}$ inhibition in the citric acid cycle. Ultimately HIF $1 \alpha$ is overexpressed in CRPC leading to increased transcription of genes responsible for glucose metabolism, proteolysis, cell survival, erythropoiesis and angiogenesis. 


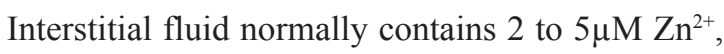
and a cytotoxic effect of $\mathrm{Zn}^{2+}$ is observed at concentrations significantly higher than this normal range [24, 2730]. A lower non-toxic dose of $\mathrm{Zn}^{2+}$ did not affect the proliferation of LNCaP prostate cancer cells (Figure 3D). Interestingly $\mathrm{Zn}^{2+}$ treatment slowed the proliferation of CRPC-like PC3 cells (Figure 3B) to a much greater degree compared to normal prostate PNT1A cells (Figure $3 C)$. However this was not due to any difference in the uptake of $\mathrm{Zn}^{2+}$ because normal PNT1A cells increased intracellular free $\mathrm{Zn}^{2+}$ equally, rapidly and to a greater degree than PC3 cells exposed to $10 \mu \mathrm{M} \mathrm{ZnCl}$ (Figure 1C). Furthermore, Masarik et al [19] and Kriedt et al [28] demonstrated that PC3 cell viability is compromised at earlier $\mathrm{Zn}^{2+}$ exposure times and lower doses than low grade LNCaP prostate cancer cells. It seems that an increase in intracellular free $\mathrm{Zn}^{2+}$ does not necessarily lead to greater proliferation as previously observed [31]. However the observation that the migration of PC3 and DU145 cells, which contain high intracellular free $\mathrm{Zn}^{2+}$ is high compared to $\mathrm{LNCaP}$ cells which contain low free $\mathrm{Zn}^{2+}$ [9] suggests a role of intracellular $\mathrm{Zn}^{2+}$ ions in generation of the nonproliferative but migratory and chemo-resistant phenotype [32] synonymous with CRPC tumors. Overall these results highlight a distinct effect of $\mathrm{Zn}^{2+}$ on CRPC-like cells and suggest that the increase in extracellular $\mathrm{Zn}^{2+}$ may not be as important as how the cells regulate and cope with a rapid increase in intracellular $\mathrm{Zn}^{2+}$. The possibility that $\mathrm{Zn}^{2+}$ homeostasis is altered in CRPC-like cancer cells compared to normal cells needs to be investigated.

In human prostate specimens' total $\mathrm{Zn}^{2+}$ concentrations decrease with PC development [2, 33-35]. In vitro, although the mean endogenous concentration of $\mathrm{Zn}^{2+}$ in LNCaP cells was higher than in PC3 cells, the $\mathrm{Zn}^{2+}$ concentrations were not compared to normal prostate cells [36]. A previous study by Qin et al. [37] reported a significant reduction in total $\mathrm{Zn}^{2+}$ in $\mathrm{LNCaP}$ cells compared to normal epithelial RWPE1 cells using ICP-MS. However, the fact that RWPE1 cells were cultured in keratinocyte serum-free medium (KSFM) which contains $0.7 \mu \mathrm{M} \mathrm{Zn}^{2+}$ [38], while LNCaP cells were grown in RPMI which does not contain any detectable amount of $\mathrm{Zn}^{2+}$ questions the validity of such results. To overcome these limitations in the current study total $\mathrm{Zn}^{2+}$ concentrations were compared by ICP-MS in four prostate cell lines (PNT1A, LNCaP, DU145 and PC3) which were all cultured in the same media (RPMI), and in the absence of any serum which may influence total $\mathrm{Zn}^{2+}$ concentrations $[20,21]$. The ICP-MS data suggests that there is no correlation between normal and cancerous PC cells in vitro in terms of total $\mathrm{Zn}^{2+}$ concentrations, although LNCaP cells did contain higher $\mathrm{Zn}^{2+}$ than PC3 cells as published previously [36].

In a normal cell, a large proportion of intracellular $\mathrm{Zn}^{2+}$ is bound and only a very small proportion is free. An increase in intracellular free $\mathrm{Zn}^{2+}$ ions (the " $\mathrm{Zn}$ wave") may therefore be more relevant in orchestrating downstream biological effects such as increased survival or migration [31, 39]. Interestingly, recent studies have revealed that while total $\mathrm{Zn}^{2+}$ is reduced in prostate cancer cells, cytosolic free $\mathrm{Zn}^{2+}$ is actually higher, emphasizing the importance of measuring free $\mathrm{Zn}^{2+}$ [37]. Such an increase in free cytosolic $\mathrm{Zn}^{2+}$ can be attained either by activation of receptors $[31,40,41]$ or by increased uptake via $\mathrm{Zn}^{2+}$ transporters/channels. Measurement of free (also called labile or loosely bound) $\mathrm{Zn}^{2+}$ using the $\mathrm{Zn}^{2+}$-specific fluorescent probe FluoZin-3 demonstrated that at baseline CRPC-like PC3 and DU145 cells contained a significantly higher concentration of free $\mathrm{Zn}^{2+}$ than normal PNT1A cells or low grade androgen-sensitive LNCaP cells. Furthermore calculation of Pearson's coefficient for the fluorescence microscopy studies indicated that, while both PC3 and PNT1A cells increased $\mathrm{Zn}^{2+}$ in the mitochondria in the first 30 min of treatment with exogenous $\mathrm{Zn}^{2+}$, only PC3 cells maintained $\mathrm{Zn}^{2+}$ in the mitochondria at $4 \mathrm{~h}$ post initiation of the treatment. It has been suggested that $\mathrm{Zn}^{2+}$ may be sequestered in the mitochondria to prevent cytotoxicity [42]. If so, then $\mathrm{Zn}^{2+}$ should have been less toxic to PC3 cells compared to PNT1A cells, which was not the case. Overall the hypothesis of $\mathrm{Zn}^{2+}$ dys-homeostasis in PC is supported by data from Masarik et al. [19] who demonstrated that the free-to-bound $\mathrm{Zn}^{2+}$ ratio was much higher in untreated PC3 cells compared to PNT1A cells. Masarik et al. also noted that $\mathrm{Zn}^{2+}$ was localised in and around nuclei and in the inner part of the cytoplasm in the form of 'spots' in PC3 cells which were not seen in PNT1A cells.

Accumulation of high mitochondrial $\mathrm{Zn}^{2+}$ concentrations in specific prostate cells results in the induction of apoptosis and the inhibition of cell growth [43]. The opposing notions of the observed ability of $\mathrm{Zn}^{2+}$ to be either anti-apoptotic or pro-apoptotic may in part be due to the ability or lack thereof of the mitochondria in different cells to respond directly to the effects of $\mathrm{Zn}^{2+}$ [43]. $\mathrm{Zn}^{2+}$ ions decrease cell viability and mitochondrial succinate dehydrogenase activity in CRPC-like PC3 cells and benign prostatic hyperplasia epithelial BPH-1 cells [44]. Further mitochondrial $\mathrm{Zn}^{2+}$ accumulation has been shown not only to severely impede mitochondrial enzymes such as aconitase, 2-oxoglutarate dehydrogenase, $\mathrm{NAD}^{+}$-dependent isocitrate dehydrogenase, and succinate dehydrogenase, but also to induce oxidative stress $[45,46]$. These studies raised the possibility that as PC3 cells accumulate greater amounts of $\mathrm{Zn}^{2+}$ for a longer period in the mitochondria they may be more sensitive to oxidative stress compared to PNT1A cells. On the contrary, CRPC-like PC3 cells are more resistant to $\mathrm{H}_{2} \mathrm{O}_{2}$ treatment than PNT1A cells, and also exogenous $\mathrm{Zn}^{2+}$ at a non-toxic dose can increase further the resistance to oxidative stress. Previously, we have shown that the survival rates of PC3 cells following treatment with either $\mathrm{H}_{2} \mathrm{O}_{2}$ or the chemotherapeutic 
5-fluorouracil were significantly greater compared to LNCaP cells via a HIF-dependent mechanism [9].

Hypoxia inducible transcription factors induce diverse genes involved in cell survival, angiogenesis, glucose metabolism and invasion and play an important role in cancer progression [47]. HIF1 $\alpha$ degradation normally occurs via oxygen- and iron-dependent prolylhydroxylation by prolyl hydroxylase domain-containing protein (PHD) [47]. CRPCs by their nature are extremely resistant to chemotherapy, and we have previously shown an association between HIF $1 \alpha$ and resistance to cytotoxic agents $[9,48]$. The observation made nearly two decades ago by Zhong and co-workers that PC 3 cells overexpress HIF $1 \alpha$ even in the presence of oxygen $[49,50]$ is a very reproducible and robust phenotypic characteristic of CRPC-like cells although the mechanism is unclear. Further the role of $\mathrm{Zn}^{2+}$ in HIF $1 \alpha$ expression is unclear. Nardinocchi et al [51] showed that exogenous $\mathrm{Zn}^{2+}$ suppressed both HIF1 $\alpha$ and HIF2 $\alpha$ protein expression. In contrast, Jeong et al. [52] reported a $\mathrm{Zn}^{2+}$-mediated dose dependent stimulation of HIF $1 \alpha$ protein expression in DU145 and PC 3 cells and that HIF1 $\alpha$ plays a crucial role in the regulation of zinc resistance [52, 53]. More recently, we have shown that $\mathrm{Zn}^{2+}$ induces expression of HIF $1 \alpha$ in normal HK-2 renal tubular cells as well as in ACHN renal cancer cells [11]. In this study we have shown a strong correlation between the concentration of free $\mathrm{Zn}^{2+}$ and HIF $1 \alpha$ expression in prostate cells (Figure 5B) but, more importantly, that exogenous $\mathrm{Zn}^{2+}$ stimulates HIF $1 \alpha$ expression in a time- and dose-dependent manner in PC3 cells with a simultaneous increase in resistance to cytotoxics such as $\mathrm{H}_{2} \mathrm{O}_{2}$ (Figure 4A). Furthermore, as knockdown of HIF $1 \alpha$ reduced survival of PC3 cells, even in the presence of $\mathrm{Zn}^{2+}$, we concluded that the $\mathrm{Zn}^{2+}$ dependent increase in resistance to oxidative stress may in part be via a HIF $1 \alpha$-dependent mechanism in CRPC-like cells.

Our current study using CRPC-like DU145 and PC3 cells confirms previous observation by Knowles et al [54] that HIF $1 \alpha$ protein expression in reduced in the presence of exogenous iron. More importantly we have establish that exogenous $\mathrm{Zn}^{2+}$ was able to reverse the reduction in HIF $1 \alpha$ expression in the presence of exogenous iron in PC3 cells (Figure 7B). Overall we postulate that increased free $\mathrm{Zn}^{2+}$ in CRPC-like PC3 and DU145 cells may displace the $\mathrm{Fe}^{2+}$ binding at the PHD site and thereby results in increased stabilization of the HIF $1 \alpha$ protein under normal oxygen conditions.

The role of zinc in prostate cancer has been investigated because of changes in the total amount of zinc compared to the normal prostate. Based on the evidence that in prostate cancer the amount of $\mathrm{Zn}$ is reduced, it was postulated that re-establishing normal intracellular $\mathrm{Zn}^{2+}$ concentrations in prostatic tumours might restore a benign phenotype in malignant prostate cells. However, in contrast Kratochvilova et al. and Holubova et al. have convincingly showed that exogenous $\mathrm{Zn}^{2+}$ drives tumour cells towards a more aggressive and resistant phenotype $[53,55]$.

In conclusion, a state of $\mathrm{Zn}^{2+}$ dys-homeostasis in PC exists as demonstrated by the increased availability and subcellular distribution of free $\mathrm{Zn}^{2+}$ in $\mathrm{PC} 3$ cells. Expression of basal HIF1 $\alpha$ correlates with free $\mathrm{Zn}^{2+}$ concentration in PC cell lines. HIF1 $\alpha$ protein can be further increased by exogenous $\mathrm{Zn}^{2+}$ in a dose- and time-dependent manner in PC3 cells. $\mathrm{Zn}^{2+}$ enhances PC3 cell survival under oxidative stress, an effect not seen in PNT1A cells or in a HIF1 $\alpha$-KD PC3 cell model. Therefore HIF $1 \alpha$ is an integral component of a $\mathrm{Zn}^{2+}$ dependent protective mechanism in PC3 cells. Based on these findings it can be hypothesized that free $\mathrm{Zn}^{2+}$ is more relevant especially in CRPC. Furthermore there are no studies which have specifically looked at the role of $\mathrm{Zn}^{2+}$ in the chemo-resistant phenotype of CRPC, although the role of HIF $1 \alpha$ as a downstream mediator of $\mathrm{Zn}^{2+}$ is well established in CRPC [9]. Further studies will be required to establish firstly, if such $\mathrm{Zn}^{2+}$ dys-homeostasis may be clinically significant through its contribution to castrateresistant PC survival and secondly, whether or not $\mathrm{Zn}^{2+}$ chelation therapies are effective in counteracting the resistance to treatment of CRPC.

\section{MATERIALS AND METHODS}

\section{Cell culture and treatment}

Normal prostate epithelial cells (PNT1A) were purchased from The European Collection of Cell Cultures (ECACC). Three human prostate cancer cell lines (PC3, DU145 and LNCaP) were purchased from the American Type Culture Collection (Manassas, VA). All cell lines were cultured in Roswell Park Memorial Institute (RPMI) medium (Scoresby, VIC) which was supplemented with $7.5 \%$ Fetal Bovine Serum (FBS), 0.4\% PenicillinStreptomycin and 2\% HEPES. HIF $1 \alpha$ knock-down PC3 cells (HIF $1 \alpha-\mathrm{KD})$ were used as previously described [9] .

\section{Western blot}

HIF $1 \alpha$ protein was analysed by Western blot using the method previously described [9] with a primary HIF $1 \alpha$ purified mouse anti-human antibody at dilution 1:1000 (BD Biosciences, USA) followed by a secondary anti-mouse horseradish peroxidase-conjugated antibody (1:5000, Bio-Rad). GAPDH was assayed as a loading control with a rabbit monoclonal GAPDH antibody (1:10000, Cell Signaling, USA).

\section{MTT cell proliferation assay}

Cells were cultured as described above and trypsinised at $80 \%$ confluency. For the MTT cell survival 
assay cells were plated into a 96-well plate $\left(1.0 \times 10^{4}\right.$ cells/well) and incubated in media containing $7.5 \%$ serum for 24 hours. For $\mathrm{Zn}^{2+}$ treatment $\mathrm{ZnCl}_{2}$ in serum free media (SFM) was added to $12.5 \mu \mathrm{M}, 25 \mu \mathrm{M}$ or 50 $\mu \mathrm{M}$, and the cells were incubated for $48 \mathrm{~h}$. For longterm cell proliferation assays cells were plated in four 24 -well plates $\left(2.5 \times 10^{4}\right.$ cells/well $)$ representative of each time point $(0,24,48$ and 72 hour) and incubated in SM for $24 \mathrm{~h}$. Next day a MTT assay was performed on one plate to determine the relative cell numbers prior to the start of zinc treatment. The values were recorded as the $0 \mathrm{hr}$ absorbance reading. Cells in the rest of the plates were treated with either $10 \mu \mathrm{M} \mathrm{ZnCl}_{2}(10 \mu \mathrm{M}$ in SFM) or serum free medium only and incubated for 24,48 or 72 hours. MTT stock solution $(5 \mathrm{mg} / \mathrm{ml})$ (Sigma Aldrich, USA) was prepared in $1 \times \mathrm{PBS}$ and $10 \mu \mathrm{L} /$ well added. After incubation with MTT solution for $1 \mathrm{~h}$ and following the solubilization of formazan crystals in acidified isopropanol the absorbance, which is directly proportional to cell numbers, was measured at a wavelength of $570 \mathrm{~nm}$ with background subtraction at $620 \mathrm{~nm}$ using a FLUOstar Optima Microplate Reader (BMG Labtech, Mornington, VIC). Data are expressed as a percentage of the $0 \mathrm{hr}$ reading taken just prior to zinc treatment.

\section{$\mathrm{H}_{2} \mathrm{O}_{2}$ survival assay}

Cells were plated on a 12 -well plate $\left(1.2 \times 10^{5}\right.$ cells/ well) and incubated in culture medium for $24 \mathrm{~h}$. For $\mathrm{Zn}^{2+}$ pre-conditioning $\mathrm{ZnCl}_{2}$ in $\mathrm{SFM}$ was added to the indicated final concentrations between $0.1 \mu \mathrm{M}$ to $50 \mu \mathrm{M}$, and the cells were incubated for $4 \mathrm{~h}$, and the media was then replaced with $\mathrm{H}_{2} \mathrm{O}_{2}(25 \mu \mathrm{M}, 50 \mu \mathrm{M}, 75 \mu \mathrm{M}$ or $100 \mu \mathrm{M})$ in SFM for $24 \mathrm{~h}$. MTT analysis was performed as described above.

\section{FluoZin-3 free $\mathrm{Zn}^{2+}$ assay}

Cells were plated on a black 96 -well plate $(1.0 \times$ $10^{4}$ cells/well) and incubated overnight. $\mathrm{Zn}^{2+}(10 \mu \mathrm{M}$ or $50 \mu \mathrm{M} \mathrm{ZnCl}_{2}$ in SFM) was added for 1,4 or $24 \mathrm{~h}$. $10 \mu \mathrm{M}$ TPEN or $500 \mu \mathrm{M} \mathrm{ZnCl}$, were added for $1 \mathrm{~h}$ for measurement of Fmin or Fmax, respectively. FluoZin-3 (AM, cell permeant, F-24195, Life Technologies) was added to a final concentration of $5 \mu \mathrm{M}(50 \mu \mathrm{l} /$ well $)$ and the 96 well plates were covered with foil to protect them from light. Samples were equilibrated for $30 \mathrm{~min}$ before the dye was removed and replaced by Hank's balanced salt solution (HBSS) for $15 \mathrm{~min}$. The resulting fluorescence was recorded on a FLUOstar Optima Microplate Reader (BMG Labtech, Mornington, VIC). Free $\mathrm{Zn}^{2+}(\mathrm{nM})$ was calculated according to the manufacturer's instructions with the formula: $\mathrm{Zn}^{2+}=\mathrm{Kd}$ $\times(\mathrm{F}-\mathrm{Fmin}) /($ Fmax $-\mathrm{F})$, where the Kd for FluoZin-3 is $15 \mathrm{nM}$.

\section{Fluorescence microscopy (FM)}

PNT1A and PC3 cells were mounted onto coverslips overnight then $\mathrm{ZnCl}_{2}(10 \mu \mathrm{M}$ in SFM) was added for 30, 60,120 or $240 \mathrm{~min}$. FluoZin-3 $(2.5 \mu \mathrm{M})$, MitoTracker Red FM (50nM) or Hoechst $33342(0.2 \mu \mathrm{g} / \mathrm{mL})$ was added for $45 \mathrm{~min}$ at $37^{\circ} \mathrm{C}$ in the dark and then fixed by treatment with $4 \%$ paraformaldehyde for $3 \mathrm{~min}$. A Nikon DS-Qi $1 \mathrm{Mc}$ camera and NIS Nikon Elements Software were used to take separate and composite images, from which mean Pearson correlation coefficient (PCC) values were calculated from 10 images per treatment per cell line.

\section{Metal analysis by Inductively Coupled Plasma Mass Spectroscopy (ICP-MS)}

For measurement of total zinc $5.0 \times 10^{5}$ cells for each cell line (PNT1A, LNCaP, DU145 and PC3) were cultured in $60 \mathrm{~mm}$ cell culture dishes in $5 \mathrm{mls}$ serum media overnight. Next day serum media was aspirated and cells were washed briefly for 10-20 seconds with $2 \mathrm{mLs}$ of Milli-Q water. A final volume of $500 \mu \mathrm{L}$ of Milli-Q water was added and cells were scraped and the lysate collected into a $1.5 \mathrm{~mL}$ eppendorf tube. Cell lysates were freezedried, nitric acid ( $50 \mu \mathrm{L}$ of $65 \%$, Suprapur, Merck) was added to each cell pellet, and the pellets were digested overnight at room temperature. The samples were heated using a heating block at $90^{\circ} \mathrm{C}$ for $20 \mathrm{~min}$ to a volume of $\sim 40 \mu \mathrm{L}$. To each sample $460 \mu \mathrm{L}$ of $1 \%(\mathrm{v} / \mathrm{v})$ of nitric acid diluent was added to a final Volume of $0.5 \mathrm{~mL}$. Measurements were made using an Agilent 7700 series ICP-MS instrument under routine multi-element operating conditions using a helium reaction gas cell. The instrument was calibrated using $0,5,10,50,100$ and $500 \mathrm{ppb}$ of certified multi- element ICP-MS standard calibration solutions (ICP-MS-CAL2-1, ICP-MS-CAL-3 and ICPMS-CAL-4, Accustandard) for a range of elements. A certified internal standard solution containing $200 \mathrm{ppb}$ of Yttrium (Y89) was used as an internal control (ICP- MSIS-MIX1-1, Accustandard).

\section{In vivo study}

The animal studies (project number A2014/05210) were approved by the Animal Ethics Committees of Austin Health, Victoria, Australia, in accordance with the guidelines laid down by the National Health and Medical Research Council of Australia's Code of Practice for the Care and Use of Animals for Experimental Purposes. Certified severe combined immunodeficiency (SCID) male mice, aged $>4$ weeks were purchased from the Animal Resource Centre (Perth, Australia) and housed in the BioResources Facility (Austin Health). PC3 cells were injected into the flanks of the mice and xenograft tumours were allowed to develop. Tumour volumes were measured daily and mice were randomised to treatment or control groups when the tumour 
volume was $>200 \mathrm{~mm}^{3}$. Treatment consisted of twice-weekly intra-peritoneal injections of $\mathrm{ZnCl}_{2}$ or the $\mathrm{Zn}^{2+}$ chelator TPEN (Sigma-Aldrich, Australia) (3 mg/Kg, $10 \mathrm{mg} / \mathrm{Kg}$ or $20 \mathrm{mg} / \mathrm{Kg}$ ) until the tumour volume exceeded $1000 \mathrm{~mm}^{3}$. Xenograft tissue was harvested for immunohistochemistry (IHC) and $\mathrm{Zn}^{2+}$ analysis. Zinc chloride was dissolved in $0.1 \% \mathrm{HCL}$ in injection water and diluted to a final concentration of $1 \mu \mathrm{g} / \mu \mathrm{L}$ in saline. TPEN (Sigma-Aldrich) was dissolved in DMSO and diluted with saline to a final concentration of $1 \mu \mathrm{g} / \mu \mathrm{L}$. The final DMSO concentration $\mathrm{w}$ as $<4.0 \%$.

\section{Data analysis}

Statistics were analysed with GraphPad Prism (Version 7). All experiments were repeated in triplicate. Values are expressed as mean \pm standard error of the mean (SEM). Statistical significance for single comparisons of normally distributed data was determined by a twoway Student's $t$ test. For multiple comparisons, one-way ANOVAs followed by the Bonferroni correction were performed. Statistical significance was determined by $p$ value $<0.05$ (borderline significant), $p<0.01$ (moderately significant) and $p<0.001$ (strongly significant).

\section{CONFLICTS OF INTEREST}

None.

\section{REFERENCES}

1. Fukada T, Yamasaki S, Nishida K, Murakami M, Hirano T. Zinc homeostasis and signaling in health and diseases: Zinc signaling. J Biol Inorg Chem. 2011; 16:1123-1134.

2. Costello LC, Franklin RB. Novel role of zinc in the regulation of prostate citrate metabolism and its implications in prostate cancer. Prostate. 1998; 35:285-296.

3. Costello LC, Franklin RB. Zinc is decreased in prostate cancer: an established relationship of prostate cancer! J Biol Inorg Chem. 2011; 16:3-8.

4. Reyes JG. Zinc transport in mammalian cells. Am J Physiol. 1996; 270:C401-410.

5. Franklin RB, Costello LC. The Important Role of the Apoptotic Effects of Zinc in the Development of Cancers. J Cell Biochem. 2009; 106:750-757.

6. Kelleher SL, McCormick NH, Velasquez V, Lopez V. Zinc in specialized secretory tissues: roles in the pancreas, prostate, and mammary gland. Adv Nutr. 2011; 2:101-111.

7. Maret W. Analyzing free zinc(II) ion concentrations in cell biology with fluorescent chelating molecules. Metallomics. 2015; 7:202-211.

8. Smith DJ, Jaggi M, Zhang W, Galich A, Du C, Sterrett SP, Smith LM, Balaji KC. Metallothioneins and resistance to cisplatin and radiation in prostate cancer. Urology. 2006; 67:1341-1347.
9. Ranasinghe WK, Xiao L, Kovac S, Chang M, Michiels C, Bolton D, Shulkes A, Baldwin GS, Patel O. The role of hypoxia-inducible factor 1alpha in determining the properties of castrate-resistant prostate cancers. PLoS ONE. 2013; 8:e54251.

10. Adler J, Parmryd I. Quantifying colocalization by correlation: the Pearson correlation coefficient is superior to the Mander's overlap coefficient. Cytometry A. 2010; 77:733-742.

11. Rao K, Sethi K, Ischia J, Gibson L, Galea L, Xiao L, Yim M, Chang M, Papa N, Bolton D, Shulkes A, Baldwin GS, Patel O. Protective effect of zinc preconditioning against renal ischemia reperfusion injury is dose dependent. PLoS ONE. 2017; 12:e0180028.

12. Haase VH. The VHL/HIF oxygen-sensing pathway and its relevance to kidney disease. Kidney Int. 2006; 69:1302-1307.

13. Kaczmarek M, Cachau RE, Topol IA, Kasprzak KS, Ghio A, Salnikow K. Metal ions-stimulated iron oxidation in hydroxylases facilitates stabilization of HIF-1 alpha protein. Toxicol Sci. 2009; 107:394-403.

14. Li Q, Chen H, Huang X, Costa M. Effects of 12 metal ions on iron regulatory protein 1 (IRP-1) and hypoxia-inducible factor-1 alpha (HIF-1alpha) and HIF-regulated genes. Toxicol Appl Pharmacol. 2006; 213:245-255.

15. Beyersmann D, Haase H. Functions of zinc in signaling, proliferation and differentiation of mammalian cells. Biometals. 2001; 14:331-341.

16. MacDonald RS. The role of zinc in growth and cell proliferation. J Nutr. 2000; 130:1500S-1508S.

17. Rudolf E, Cervinka M. External zinc stimulates proliferation of tumor Hep-2 cells by active modulation of key signaling pathways. J Trace Elem Med Biol. 2008; 22:149-161.

18. Liang JY, Liu YY, Zou J, Franklin RB, Costello LC, Feng P. Inhibitory effect of zinc on human prostatic carcinoma cell growth. Prostate. 1999; 40:200-207.

19. Masarik M, Gumulec J, Hlavna M, Sztalmachova M, Babula P, Raudenska M, Pavkova-Goldbergova M, Cernei N, Sochor J, Zitka O, Ruttkay-Nedecky B, Krizkova S, Adam V, et al. Monitoring of the prostate tumour cells redox state and real-time proliferation by novel biophysical techniques and fluorescent staining. Integr Biol. 2012; 4:672-684.

20. Haase H, Hebel S, Engelhardt G, Rink L. The biochemical effects of extracellular $\mathrm{Zn}(2+)$ and other metal ions are severely affected by their speciation in cell culture media. Metallomics. 2015; 7:102-111.

21. Marshall KM, Laval M, Estacio O, Hudson DF, Kalitsis P, Shulkes A, Baldwin GS, Patel O. Activation by zinc of the human gastrin gene promoter in colon cancer cells in vitro and in vivo. Metallomics. 2015; 7:1390-1398.

22. Hong SH, Choi YS, Cho HJ, Lee JY, Kim JC, Hwang TK, Kim SW. Antiproliferative effects of zinc-citrate compound on hormone refractory prostate cancer. Chin J Cancer Res. 2012; 24:124-129.

23. Franklin RB, Costello LC. Zinc as an anti-tumor agent in prostate cancer and in other cancers. Arch Biochem Biophys. 2007; 463:211-217. 
24. Shah MR, Kriedt CL, Lents NH, Hoyer MK, Jamaluddin $\mathrm{N}$, Klein C, Baldassare J. Direct intra-tumoral injection of zinc-acetate halts tumor growth in a xenograft model of prostate cancer. J Exp Clin Cancer Res. 2009; 28:84.

25. Feng P, Li TL, Guan ZX, Franklin RB, Costello LC. Effect of zinc on prostatic tumorigenicity in nude mice. Ann N Y Acad Sci. 2003; 1010:316-320.

26. Costello LC, Franklin RB. Decreased zinc in the development and progression of malignancy: an important common relationship and potential for prevention and treatment of carcinomas. Expert Opin Ther Targets. 2017; 21:51-66.

27. Magneson GR, Puvathingal JM, Ray WJ Jr. The concentrations of free $\mathrm{Mg} 2+$ and free $\mathrm{Zn} 2+$ in equine blood plasma. J Biol Chem. 1987; 262:11140-11148.

28. Kriedt CL, Baldassare J, Shah M, Klein C. Zinc functions as a cytotoxic agent for prostate cancer cells independent of culture and growth conditions. J Exp Ther Oncol. 2010; 8:287-295.

29. Hasumi M, Suzuki K, Matsui H, Koike H, Ito K, Yamanaka $\mathrm{H}$. Regulation of metallothionein and zinc transporter expression in human prostate cancer cells and tissues. Cancer Lett. 2003; 200:187-195.

30. Tsui KH, Chang PL, Juang HH. Zinc blocks gene expression of mitochondrial aconitase in human prostatic carcinoma cells. Int J Cancer. 2006; 118:609-615.

31. Chang M, Xiao L, Shulkes A, Baldwin GS, Patel O. Zinc Ions Mediate Gastrin Expression, Proliferation, and Migration Downstream of the Cholecystokinin-2 Receptor. Endocrinology. 2016; 157:4706-4719.

32. Yano S, Miwa S, Mii S, Hiroshima Y, Uehara F, Yamamoto M, Kishimoto H, Tazawa H, Bouvet M, Fujiwara T, Hoffman RM. Invading cancer cells are predominantly in G0/G1 resulting in chemoresistance demonstrated by realtime FUCCI imaging. Cell Cycle. 2014; 13:953-960.

33. Zaichick VY, Sviridova TV, Zaichick SV. Zinc in the human prostate gland: Normal, hyperplastic and cancerous. Int Urol Nephrol. 1997; 29:565-574.

34. Kerr WK, Keresteci AG, Mayoh H. The distribution of zinc within the human prostate. Cancer. 1960; 13:550-554.

35. Gumulec J, Masarik M, Adam V, Eckschlager T, Provaznik I, Kizek R. Serum and tissue zinc in epithelial malignancies: a meta-analysis. PLoS ONE. 2014; 9:e99790.

36. Costello LC, Liu Y, Zou J, Franklin RB. Evidence for a zinc uptake transporter in human prostate cancer cells which is regulated by prolactin and testosterone. J Biol Chem. 1999; 274:17499-17504.

37. Qin Y, Miranda JG, Stoddard CI, Dean KM, Galati DF, Palmer AE. Direct comparison of a genetically encoded sensor and small molecule indicator: implications for quantification of cytosolic Zn(2+). ACS Chem Biol. 2013; 8:2366-2371.

38. Huang L, Kirschke CP, Zhang Y. Decreased intracellular zinc in human tumorigenic prostate epithelial cells: a possible role in prostate cancer progression. Cancer cell international. 2006; 6:10.
39. Maret W. Zinc biochemistry: from a single zinc enzyme to a key element of life. Adv Nutr. 2013; 4:82-91.

40. Sanchez-Blazquez P, Rodriguez-Munoz M, Bailon C, Garzon J. GPCRs promote the release of zinc ions mediated by nNOS/NO and the redox transducer RGSZ2 protein. Antioxid Redox Signal. 2012; 17:1163-1177.

41. Kaltenberg J, Plum LM, Ober-Blobaum JL, Honscheid A, Rink L, Haase H. Zinc signals promote IL-2-dependent proliferation of T cells. Eur J Immunol. 2010; 40:1496-1503.

42. Lu Q, Haragopal H, Slepchenko KG, Stork C, Li YV. Intracellular zinc distribution in mitochondria, ER and the Golgi apparatus. Int J Physiol Pathophysiol Pharmacol. 2016; 8:35-43.

43. Feng P, Liang JY, Li TL, Guan ZX, Zou J, Franklin RB, Costello LC. Zinc induces mitochondria apoptogenesis in prostate cells. Mol Urol. 2000; 4:31-36.

44. Untergasser G, Rumpold H, Plas E, Witkowski M, Pfister G, Berger P. High levels of zinc ions induce loss of mitochondrial potential and degradation of antiapoptotic Bcl-2 protein in in vitro cultivated human prostate epithelial cells. Biochem Biophys Res Commun. 2000; 279:607-614.

45. Lemire J, Mailloux R, Appanna VD. Zinc toxicity alters mitochondrial metabolism and leads to decreased ATP production in hepatocytes. J Appl Toxicol. 2008; 28:175-182.

46. McCord MC, Aizenman E. The role of intracellular zinc release in aging, oxidative stress, and Alzheimer's disease. Front Aging Neurosci. 2014; 6:77.

47. Ranasinghe WK, Baldwin GS, Bolton D, Shulkes A, Ischia J, Patel O. HIF1alpha expression under normoxia in prostate cancer--which pathways to target? J Urol. 2015; 193:763-770.

48. Tannock IF, de Wit R, Berry WR, Horti J, Pluzanska A, Chi KN, Oudard S, Theodore C, James ND, Turesson I, Rosenthal MA, Eisenberger MA, Investigators TAX. Docetaxel plus prednisone or mitoxantrone plus prednisone for advanced prostate cancer. N Engl J Med. 2004; 351:1502-1512.

49. Zhong H, Agani F, Baccala AA, Laughner E, RiosecoCamacho N, Isaacs WB, Simons JW, Semenza GL. Increased expression of hypoxia inducible factor-1alpha in rat and human prostate cancer. Cancer Res. 1998; 58:5280-5284.

50. Zhong H, Chiles K, Feldser D, Laughner E, Hanrahan C, Georgescu MM, Simons JW, Semenza GL. Modulation of hypoxia-inducible factor 1alpha expression by the epidermal growth factor/phosphatidylinositol 3-kinase/ PTEN/AKT/FRAP pathway in human prostate cancer cells: implications for tumor angiogenesis and therapeutics. Cancer Res. 2000; 60:1541-1545.

51. Nardinocchi L, Pantisano V, Puca R, Porru M, Aiello A, Grasselli A, Leonetti C, Safran M, Rechavi G, Givol D, Farsetti A, D'Orazi G.Zinc downregulates HIF-1 $\alpha$ and inhibits its activity in tumor cells in vitro and in vivo. PLoS ONE. 2010; 5:e15048.

52. Jeong CW, Yoon CY, Jeong SJ, Hong SK, Byun SS, Kwak C, Lee SE. The Role of Hypoxia-Inducible Factor-1alpha 
and -2alpha in Androgen Insensitive Prostate Cancer Cells. Urol Oncol. 2013; 31:1448-56.

53. Holubova M, Axmanova M, Gumulec J, Raudenska M, Sztalmachova M, Babula P, Adam V, Kizek R, Masarik M. KRAS NF-kappaB is involved in the development of zinc resistance and reduced curability in prostate cancer. Metallomics. 2014; 6:1240-1253.

54. Knowles HJ, Raval RR, Harris AL, Ratcliffe PJ. Effect of ascorbate on the activity of hypoxia-inducible factor in cancer cells. Cancer Res. 2003; 63:1764-1768.
55. Kratochvilova M, Raudenska M, Heger Z, Richtera L, Cernei N, Adam V, Babula P, Novakova M, Masarik M, Gumulec J. Amino Acid Profiling of Zinc Resistant Prostate Cancer Cell Lines: Associations With Cancer Progression. Prostate. 2017; 77:604-616. 